\title{
Bioactive Peptides in Ovine and Caprine Cheeselike Systems Prepared with Proteases from Cynara cardunculus
}

\author{
S. V. Silva,* A. Pihlanto,† and F. X. Malcata*1 \\ *Escola Superior de Biotecnologia, Universidade Católica Portuguesa, Rua Dr. António Bernardino de Almeida, P-4200-072 Porto, Portugal \\ †MTT Agrifood Research Finland, Food Research, FIN-31600 Jokioinen, Finland
}

\begin{abstract}
The potential angiotensin-converting enzyme (ACE) inhibitory and antioxidant activities of peptides in water-soluble extracts, obtained from raw and sterilized ovine and caprine cheeselike systems coagulated with enzymes from the plant Cynara cardunculus, were assessed. Prior to the assay, the 3,000-Da permeate from 45-d-old cheeselike systems was fractionated by tandem chromatographic techniques. Several peaks were obtained in each chromatogram, but only some were associated with ACE-inhibitory or antioxidant activity or both. Peptides Tyr-Gln-Glu-Pro, Val-Pro-Lys-ValLys, and Tyr-Gln-Glu-Pro-Val-Leu-Gly-Pro-* from $\beta$-casein, as well as Arg-Pro-Lys and Arg-Pro-Lys-His-ProIle-Lys-His-* from $\alpha_{\mathrm{s} 1}$-casein exhibited ACE-inhibitory activity. Peptides released upon cleavage of the peptide bond Leu190-Tyr191 (either in ovine or caprine $\beta$-casein), and corresponding to the $\beta$-casein sequence TyrGln-Glu-Pro-*, possessed antioxidant activity.
\end{abstract}

Key words: plant protease, ovine cheese, caprine cheese, angiotensin-converting enzyme inhibition

\section{INTRODUCTION}

Biologically active peptides are of particular interest in food science and nutrition, because they can play several physiological roles. Hidden (or at least inactive) within the AA sequence of dairy proteins, a class of such peptides can be released (or activated) in vivo during gastrointestinal digestion, or upstream during food processing via specific, enzyme-mediated proteolysis (Silva and Malcata, 2005a), and eventually be absorbed into the bloodstream.

Ripened cheese is one of the most important dairy products worldwide. It typically contains numerous peptides that originate mainly from $\mathrm{CN}$ breakdown during ripening. Such peptides contribute to the flavor, taste, and texture of the final product. Among the bioac-

Received September 5, 2005.

Accepted April 3, 2006.

${ }^{1}$ Corresponding author: fxmalcata@esb.ucp.pt tivities attributed to those peptides are angiotensinconverting enzyme (ACE)-inhibitory activity, opioid activity, and the ability to sequester calcium and other minerals; thus acting as biocarriers (Addeo et al., 1992; Meisel et al., 1997; Smacchi and Gobbetti, 1998; Saito et al., 2000; Gómez-Ruiz et al., 2002; Sforza et al., 2003).

In the Iberian Peninsula, several raw ovine and caprine milk cheeses, which are highly appreciated for their unique organoleptic characteristics, have been manufactured on the farm level since ancient times, with extracts of the flowers of Cynara cardunculus as the coagulant. After flowers are collected from mature plants, they are dried in the open air in the shade before use, stored in a dry place, and sold at local markets. Their milk-clotting activity is caused by 2 aspartic proteases, cardosins $\mathrm{A}$ and $\mathrm{B}$, which resemble chymosin and pepsin, respectively, in activity and specificity (Verıssimo et al., 1995). Cardosin A is a proteolytic enzyme' that is specific toward the Phe105-Met106 bond of $\kappa$ $\mathrm{CN}$, whereas cardosin $\mathrm{B}$ is a nonspecific, highly proteolytic enzyme. No toxicity to humans has ever been found for either of those enzymes. To our knowledge, no data are currently available concerning bioactive peptides from ovine or caprine milk cheeses manufactured with plant enzymes; only the research efforts encompassing the total antioxidant content of breast milk (VanderJagt et al., 2001), the antioxidant activity of bovine milk following 2 different analytical methods (Chen et al., 2003), and evaluations of the antioxidant activity of $\mathrm{CN}$ and CN-derived peptides (Suetsuna et al., 2000; Rival et al., 2001).

In particular, ACE (EC 3.4.15.1) is important in blood pressure regulation, so its inhibition may actually prevent hypertension (Meisel, 1998). This dipeptidyl carboxypeptidase is a glycoprotein peptidyldipeptide hydrolase, which is able to release histidyl-leucine from angiotensin I (a relatively inactive decapeptide) into angiotensin II, thus increasing the blood pressure and the alderosterone content, and inactivating the depressor action of bradykinin. Peptides bearing ACEinhibitory activity have been found in several kinds of cheeses (Addeo et al., 1992; Meisel et al., 1997; Smacchi and Gobbeti, 1998; Saito et al., 2000; Gómez-Ruiz et al., 2002, 2004; Sforza et al., 2003). Their C-terminal 
tripeptide sequence is the structural feature governing such inhibitory response (Maruyama et al., 1987). In addition, Meisel (1993) indicated that the ACE-binding pocket exhibits a preference for hydrophobic AA. To measure ACE activity and inhibition thereof in vitro, the method of Cushman and Cheung (1971) is often used. This particularly sensitive spectrophotometric assay determines the amount of hippuric acid formed from hippuryl-L-histidyl-L-leucine via the action of ACE. Recently, a (spectrophotometric) diagnostic assay designed to measure ACE activity was transformed into an enzyme inhibition assay and further optimized, which led to a more sensitive yet less expensive assay; it takes advantage of furanacryloyl-Phe-Gly-Gly as the substrate, and uses rabbit lung acetone extract as standard of activity (Vermeirssen et al., 2002).

On the other hand, antioxidant activity is accounted for by compounds able to protect biological systems against the potential harmful effects of processes or reactions that cause excessive degrees of oxidation, and that may thus be responsible for cellular damage. Several chemical and physicochemical methodologies have been proposed and used to monitor oxidation processes; some allow direct quantification of free radical production and its inhibition by antioxidants, whereas others indirectly assess the effectiveness of antioxidants in preventing oxidative damage (Antolovich et al., 2002). Accelerated stability tests, measurement of the ability to bring about diene conjugation, the thiobarbituric acid-reactive substance assay, measurement of hexanal and related end products, and quantification of free radicals are but a few examples. Among those of the latest type, the 2,2'-azino-bis-(3-ethylbenzothiazoline)6 -sulfonic acid (ABTS) assay is one of the most effective, and hence is commonly used.

The aim of this work was thus to find and characterize peptides with potential ACE-inhibitory and antioxidant activities in raw and sterilized ovine and caprine cheeselike systems, manufactured with enzymes from C. cardunculus as the clotting agent.

\section{MATERIALS AND METHODS}

\section{Enzyme Source}

The plant proteases were obtained via maceration of $0.6 \mathrm{~g}$ of dry flowers of C. cardunculus in $10 \mathrm{~mL}$ of water. The solution was then kept refrigerated until use (no filtration was needed, as it remained limpid).

Cardosins in the aforementioned crude extract of $C$. cardunculus were isolated and purified, following the procedure described by Silva et al. (2003). The lyophilized enzymes were reconstituted in water, just prior to use, up to $0.0035 \mathrm{~kg} / \mathrm{L}$.

\section{Cheese Making and Sampling}

Ovine (or caprine) milk was collected from the sheep (or goat) flocks on the morning of cheese making. Each batch of milk was then divided in 2 equal portions: one portion was heated at $110^{\circ} \mathrm{C}$ for $10 \mathrm{~min}$, whereas the other received no thermal treatment. Milk sterility (for the first batch) was checked as the absence of microorganisms on plate count agar incubated at $30^{\circ} \mathrm{C}$ for 48 $\mathrm{h}$ (Tavaria and Malcata, 1998). Cheeses were manufactured on the same day from raw ovine (or caprine) milk, and from sterilized ovine (or caprine) milk. Portions of $50 \mathrm{~mL}$ of each kind of milk (ovine or caprine) were placed in $100-\mathrm{mL}$ sterilized flasks; then $0.200 \mathrm{~mL}$ of test enzyme solution (crude aqueous extract, or purified cardosin A or B) was added to the milk under sterile conditions and incubated at $28^{\circ} \mathrm{C}$ until coagulation occurred (approximately $45 \mathrm{~min}$ ). The curd was then cut, stirred, and allowed to set to permit draining, again under sterile conditions. The whey produced was removed aseptically by opening the flasks every $15 \mathrm{~min}$ throughout a period of $1.5 \mathrm{~h}$. The flasks were placed in a chamber maintained at $10^{\circ} \mathrm{C}$. For further analyses, 45-d-old cheeses were selected at random.

\section{Preparation of Water-Soluble Extracts}

Water-soluble extracts (WSE) and water-insoluble extracts of cheeselike systems were prepared following the procedure of Kuchroo and Fox (1982). The cheeselike system was homogenized in a stomacher (Seward, London, UK) at $20^{\circ} \mathrm{C}$ for $10 \mathrm{~min}$ with twice its weight of water. The slurry was held at $40^{\circ} \mathrm{C}$ for $1 \mathrm{~h}$, and then centrifuged at $3,000 \times \mathrm{g}$, at $4^{\circ} \mathrm{C}$ for $30 \mathrm{~min}$. The resulting supernatants were filtered through glass wool, freezedried, and kept at $-20^{\circ} \mathrm{C}$ until use.

A 20 -mg quantity of WSE was reconstituted in $600 \mu \mathrm{L}$ of water, and $500 \mu \mathrm{L}$ of this solution was then filtered through a Centriprep hydrophilic 3,000-Da cutoff membrane (Amicon, Beverly, MA) prior to analysis.

\section{Purification of Peptides}

The freeze-dried WSE samples $(10 \mathrm{mg})$ were dissolved in $1 \mathrm{~mL}$ of $50 \%$ (vol/vol) trifluoroacetic acid (TFA) in water and filtered through a $0.45-\mu \mathrm{m}$ cellulose acetate filter. This solution was used to further fractionate the peptides present in the WSE. Aliquots $(100 \mu \mathrm{L})$ were applied to a reversed-phase column (SuperPak Pep-S, $4.0 \times 250 \mathrm{~mm}, 5 \mu \mathrm{m}$, after a Pep-S precolumn, $4.0 \times 10 \mathrm{~mm}, 5 \mu \mathrm{m}$, both from Pharmacia, Uppsala, Sweden). Elution was at $40^{\circ} \mathrm{C}$ via a mobile phase of 2 solvents—solvent A: $0.05 \%$ (vol/vol) TFA in water; and solvent B: $0.05 \%(\mathrm{vol} / \mathrm{vol})$ TFA in acetonitrile:water (9:1) —at a flow rate of $1.0 \mathrm{~mL} / \mathrm{min}$, starting with $98 \%$ 
Table 1. Average angiotensin-converting enzyme-inhibitory activity (\%) of water-soluble extracts of raw and sterilized ovine and caprine cheeselike systems, manufactured separately with cardosin A, cardosin B, or a crude aqueous extract of Cynara cardunculus

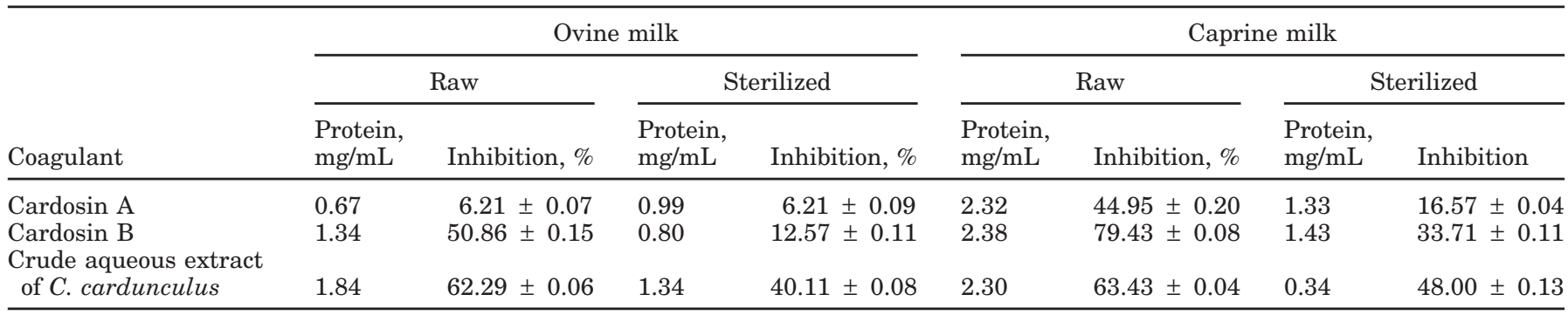

(vol/vol) solvent A, passing through a linear gradient from 2 to $60 \%$ (vol/vol) solvent B over $45 \mathrm{~min}$, another linear gradient from 60 to $100 \%$ (vol/vol) solvent B for $2 \mathrm{~min}, 100 \%$ (vol/vol) solvent B for $5 \mathrm{~min}$, and a linear gradient from 98 to $2 \%$ (vol/vol) solvent B for $2 \mathrm{~min}$, and ending with $2 \%$ (vol/vol) solvent B for $2 \mathrm{~min}$. Detection was by spectrophotometry at $214 \mathrm{~nm}$. The fractions were collected based on their peak assignments. This step was repeated 5 times, and the fractions from the various chromatographic runs were pooled and dried in a vacuum.

\section{Estimation of ACE-Inhibitory Activity}

Inhibition of ACE was assayed by the method of Vermeirssen et al. (2002). The ACE reagent (containing $0.5 \mathrm{mmol} / \mathrm{L}$ of $\mathrm{N}$-[3-(2-furyl)acryloyl]-L-phenylalanylglycylglycine, with stabilizer and buffer at $\mathrm{pH} 8.2$; Sigma, St. Louis, MO) was reconstituted in $5 \mathrm{~mL}$ of water. The ACE from rabbit lung (Sigma) was reconstituted with demineralized water $(0.2 \mathrm{U} / \mathrm{mL})$ and diluted to $1: 3(\mathrm{vol} / \mathrm{vol})$ before use.

Each aliquot $(125 \mu \mathrm{L})$ of sample was mixed and preincubated, at $37^{\circ} \mathrm{C}$ for $2 \mathrm{~min}$, with $125 \mu \mathrm{L}$ of ACE reagent. After adding $25 \mu \mathrm{L}$ of ACE reagent to this suspension, the reaction mixture was further incubated at $37^{\circ} \mathrm{C}$ for $5 \mathrm{~min}$. Subsequently, absorbance at $340 \mathrm{~nm}$ was measured against demineralized water (control) in the heated cuvette holder $\left(37^{\circ} \mathrm{C}\right)$ of a UV-visible spectrophotometer, over a time interval of $10 \mathrm{~min}$.

The inhibitory activity was expressed as the percentage of ACE inhibition per milligram of protein, except for WSE, in which the activity was calculated as the amount of water-soluble nitrogen needed to inhibit 50\% of ACE activity $\left(\mathbf{I C}_{\mathbf{5 0}}\right)$. The activity of each sample was tested in triplicate, and their average was used as a datum point. A positive control (1 $\mathrm{m} M$ captopril; Sigma), which is known to inhibit ACE, was also included in the assay program.

\section{Estimation of Antioxidant Activity}

The antioxidant activity of either WSE or the isolated peptides thereof was assayed according to the method described by Re et al. (1999). 2,2'-Azino-bis-(3-ethylbenzothiazoline)-6-sulfonic acid was dissolved in water to a $7 \mathrm{~m} M$ concentration. To prepare the $\mathrm{ABTS}^{\bullet+}$ radical specifically needed for this test, the ABTS aqueous solution was oxidized via treatment with $2.45 \mathrm{~m} M$ potassium persulfate (1:0.5) for 12 to $16 \mathrm{~h}$ in the dark, and then diluted in $0.1 \mathrm{~mol} / \mathrm{L}$ of phosphate buffer $(\mathrm{pH} 7.4)$ prior to assaying, which yielded a typical absorbance of $0.70 \pm 0.02$ at $734 \mathrm{~nm}$ after equilibration at $30^{\circ} \mathrm{C}$. A $10-\mu \mathrm{L}$ quantity of sample (or Trolox, as positive control) was added to $1 \mathrm{~mL}$ of diluted $\mathrm{ABTS}^{\bullet+}$ solution and incubated at $30^{\circ} \mathrm{C}$ for $10 \mathrm{~min}$. Scavenging of the ABTS ${ }^{\bullet+}$ radical was followed by monitoring the decrease in absorbance at $734 \mathrm{~nm}$. A reading was taken 1 min after initial mixing and then periodically up to $6 \mathrm{~min}$. A solvent blank was run in each assay (negative control). All determinations were carried out in triplicate, and their average was used as a datum point. The percentage inhibition of absorbance at $734 \mathrm{~nm}$ was calculated and plotted as a function of the concentration of the reference antioxidant (Trolox).

\section{Sequencing of Peptides}

The peptides that exhibited ACE-inhibitory activity were sequenced by Edman degradation using a model 491 automated, pulsed liquid-phase protein-peptide sequencer (Applied Biosystems, Foster City, CA). The AA released were detected as their phenylthiohydantoin derivatives. The partial sequence thus obtained was checked against the (known) sequence of $\mathrm{CN}$ in reference databases (BLAST at the National Center for Biotechnology Information, http://www.ncbi.nlm.nih.gov/ BLAST), in attempts to identify the specific peptide bonds cleaved by the enzymes under consideration.

\section{Determination of Protein Content}

The protein (peptide) concentrations were determined by the phenol reagent method for biological fluids using the Micro Protein Determination kit (Sigma). 
Table 2. Molecular characteristics of peptides identified in the permeate of water-soluble extracts of raw and sterilized ovine cheeselike systems, manufactured separately with cardosin A, cardosin B, or a crude aqueous extract of Cynara cardunculus, and corresponding angiotensin-converting enzyme (ACE)-inhibitory and antioxidant activities $^{1}$

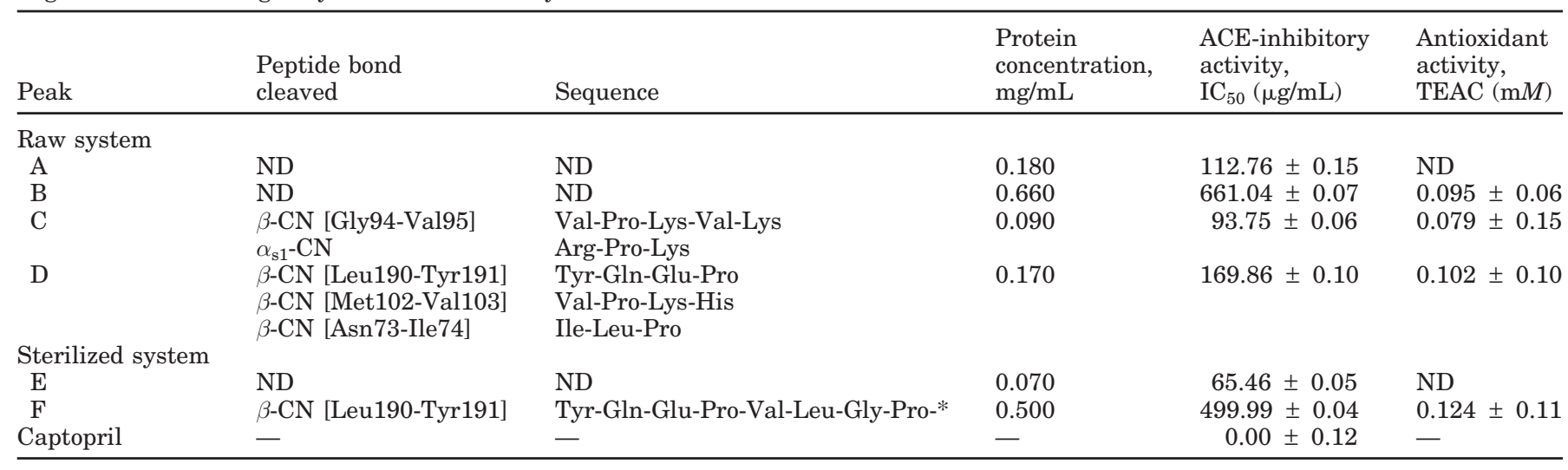

${ }^{1}$ Peaks shown in Figure 1. $\mathrm{IC}_{50}=$ amount of water-soluble nitrogen needed to inhibit $50 \%$ of ACE activity; TEAC = Trolox-equivalent antioxidant capacity; ND = not determined.

\section{RESULTS AND DISCUSSION}

Data pertaining to the ACE-inhibitory activity of the WSE from ovine and caprine milk cheeselike systems manufactured with the various coagulants, namely car$\operatorname{dosin} \mathrm{A}$, cardosin B, and crude aqueous extracts of $C$. cardunculus, are presented in Table 1. Typical elution profiles of the 3,000-Da permeate from raw and sterilized ovine and caprine milk cheeselike systems, manufactured with the aforementioned coagulants, are shown in Figures 1 and 2. The results obtained via sequencing, as well as those referring to protein content, ACE-inhibitory activity, and antioxidant activity of the peptides isolated by HPLC, are depicted in Tables 2 and 3.

The most obvious differences between the peptide profiles in Figures 1 and 2 can be ascribed to the use of raw vs. sterilized milk. Heat treatment of cheesemaking milk is intended to ensure the safety of the feedstock and the final product via elimination of adventitious, pathogenic microflora (Hermier and Cerf, 2000). Furthermore, cheese makers sometimes heat milk prior to cheese manufacture to increase cheese yield (Calvo et al., 1992). However, interactions of whey proteins with CN micelles brought about by heating milk do

Table 3. Molecular characteristics of peptides identified in the permeate of water-soluble extracts of raw and sterilized caprine cheeselike systems, manufactured separately with cardosin A, cardosin B, or a crude aqueous extract of Cynara cardunculus, and corresponding angiotensin-converting enzyme (ACE)-inhibitory and antioxidant activities ${ }^{1}$

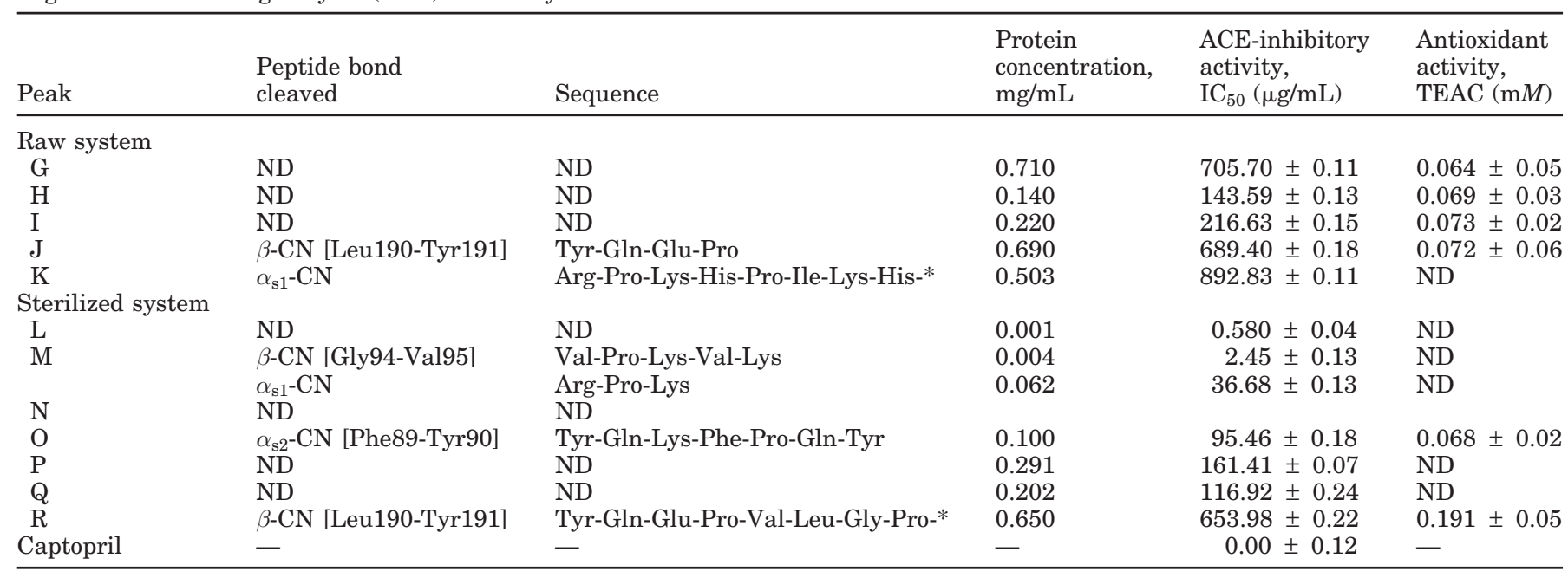

${ }^{1}$ Peaks shown in Figure 2. $\mathrm{IC}_{50}=$ amount of water-soluble nitrogen needed to inhibit $50 \%$ of ACE activity; TEAC = Trolox-equivalent antioxidant capacity; ND = not determined. 


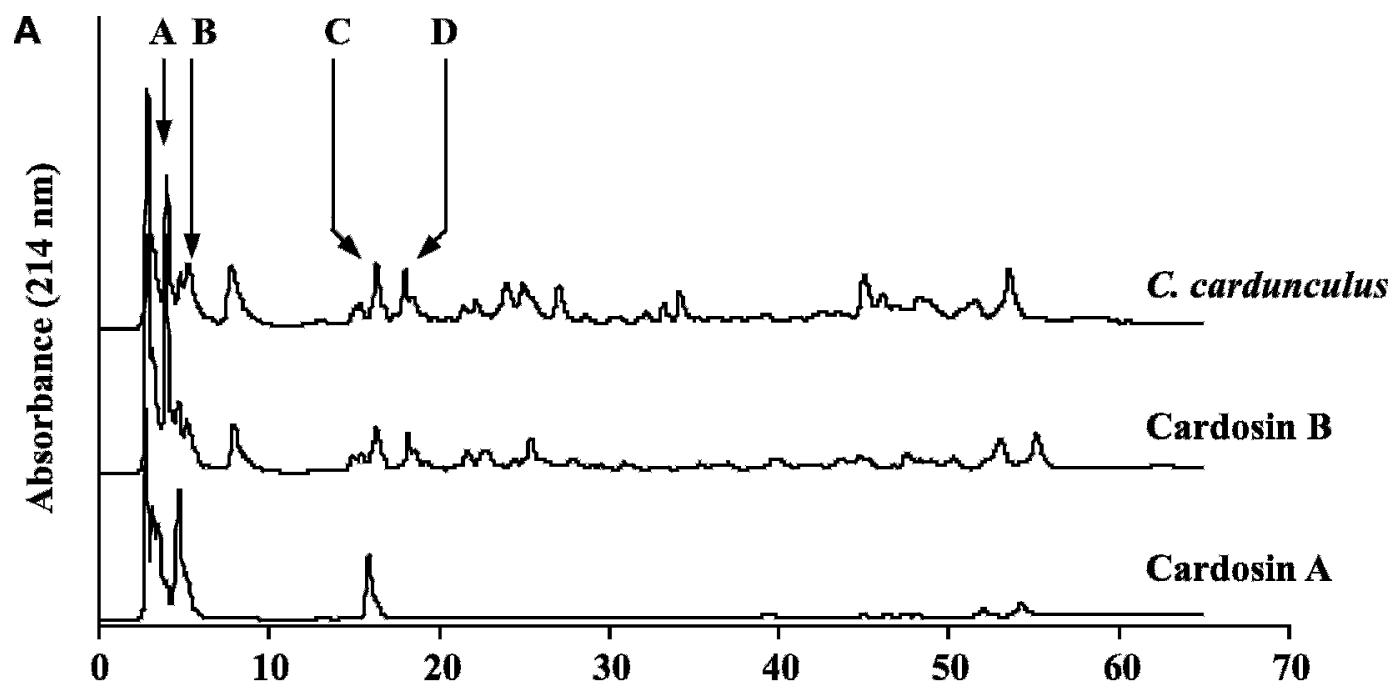

B

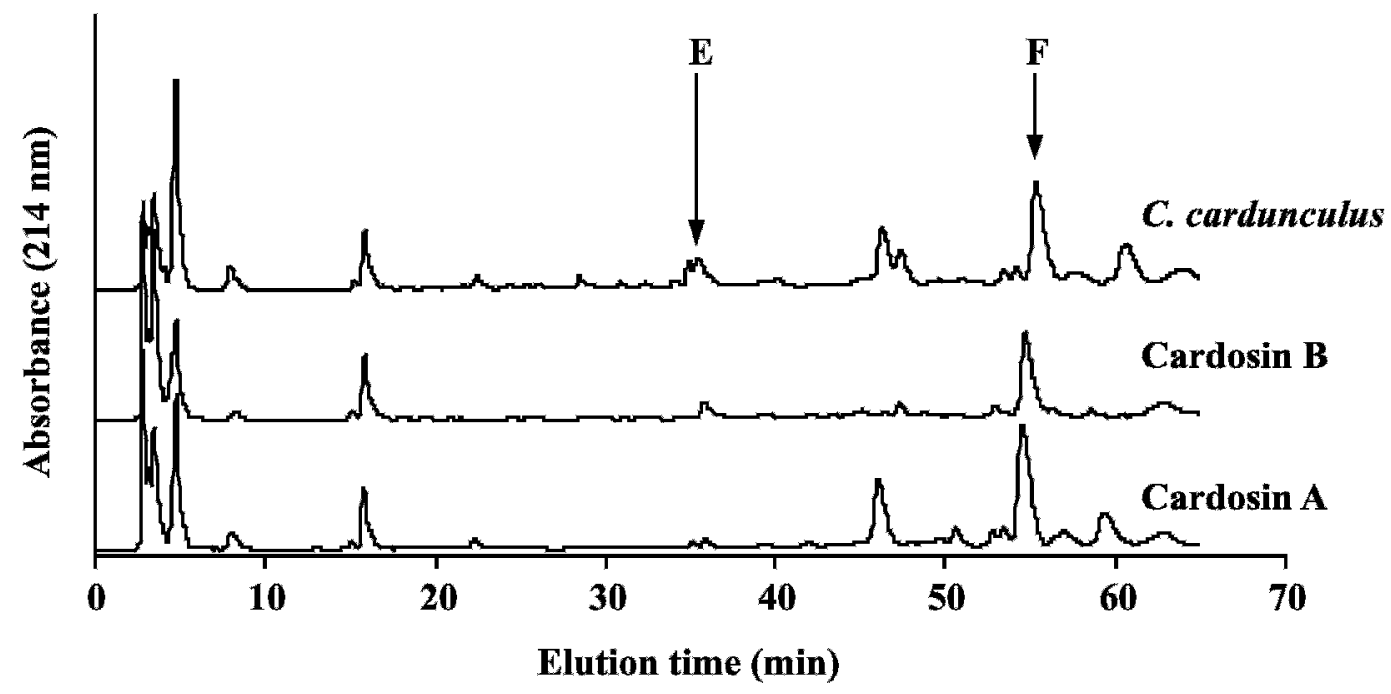

Figure 1. Reversed-phase HPLC chromatograms of the 3,000-Da permeate of water-soluble extracts of (A) raw and (B) sterilized ovine cheeselike systems, manufactured separately with cardosin A, cardosin B, or a crude aqueous extract of Cynara cardunculus. Peaks labeled A to $\mathrm{F}$ correspond to peptides identified in Table 2.

interfere with the rennet coagulation process, hence leading to longer coagulation times as well as weaker curd structures (Dalgleish, 1987; Banks, 1990; Singh and Waungana, 2001). The resulting cheese is known to tend to develop an atypical flavor and texture afterward during ripening, which in turn depends quantitatively mainly on the extent of proteolysis and qualitatively on the profile of proteolysis. In such a case, the coagulant retained in the curd is mainly responsible for $\mathrm{CN}$ breakdown, which may account for the results obtained as compared with those of raw milk, in which the mi- croflora also play an important role (especially in terms of secondary proteolysis).

Higher ACE-inhibitory activity was found in the WSE of cheeselike systems obtained from raw rather than sterilized milk, and a higher $\mathrm{IC}_{50}$ against $\mathrm{ACE}$ was detected for caprine rather than ovine cheeselike systems (in which the extent of enzyme-mediated proteolysis was also higher). Similar results were found by Silva and Malcata (2005b) concerning proteolysis of ovine vs. caprine milk $\mathrm{CN}$ via enzymes contributed by $C$. cardunculus. 

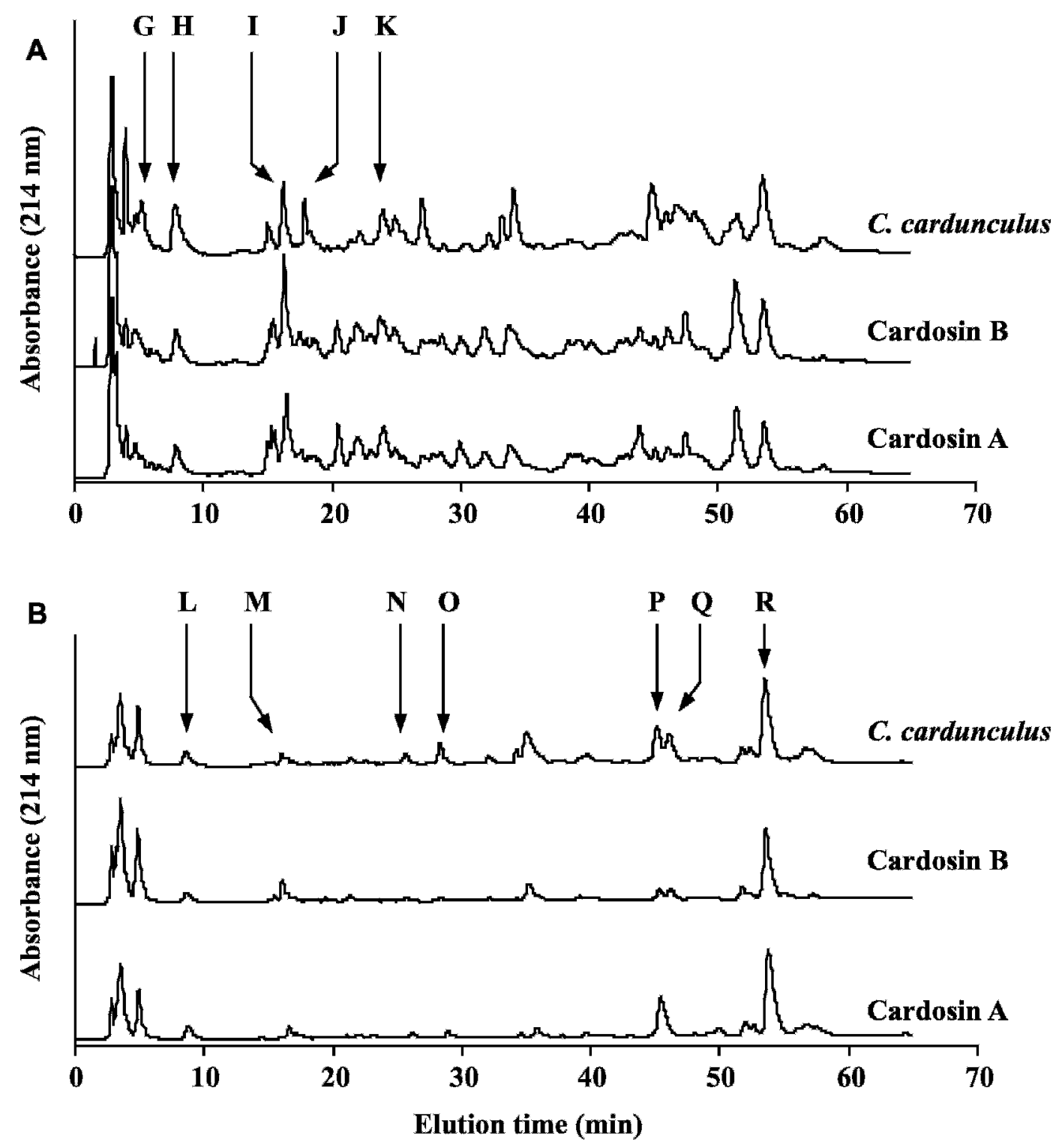

Figure 2. Reversed-phase HPLC chromatograms of the 3,000-Da permeate of the water-soluble extracts of (A) raw and (B) sterilized caprine cheeselike systems, manufactured separately with cardosin A, cardosin B, or a crude aqueous extract of Cynara cardunculus. Peaks labeled $\mathrm{G}$ to $\mathrm{R}$ correspond to peptides identified in Table 3.

Among the 3 types of coagulants tested, the lowest effect was noticed in cheeselike systems produced with cardosin $\mathrm{A}$, and the highest with the crude aqueous extract. Cardosin A is the most abundant cardosin in crude aqueous extracts of $C$. cardunculus (Frazão et al., 1999); its specificity is believed to be similar to that of chymosin. Cardosin B resembles pepsin in terms of kinetic behavior (Veríssimo et al., 1995) and is also known to possess nonspecific proteolytic activity. In the crude aqueous extract, a synergistic action apparently takes place between the 2 cardosins, which could ex- plain the actual results obtained. Concerning the peptide profile of the corresponding WSE (Figures 1 and 2 ), several peaks appear in each chromatogram, but only some of them show ACE-inhibitory or antioxidant activities or both (Tables 2 and 3).

In raw ovine cheeselike systems, only 4 peptides were found to have ACE-inhibitory activity. All of them were produced via the action of cardosin B, either as such or as a crude mixture in the aqueous extract of $C$. cardunculus, whereas only one was formed in cheeselike systems manufactured with cardosin A. The peptide de- 
noted as $\mathrm{C}$ had the highest activity $\left(\mathrm{IC}_{50}=93.75 \mu \mathrm{g} /\right.$ $\mathrm{mL}$ ), whereas the peptide denoted as B possessed the lowest $\left(\mathrm{IC}_{50}=661.04 \mu \mathrm{g} / \mathrm{mL}\right)$.

Very few peptides were present in the 3,000-Da permeate of sterilized ovine cheeselike systems, and only 2 peptides were shown to possess ACE-inhibitory activity $\left(\mathrm{IC}_{50}=65.46\right.$ for the peptide denoted as $\mathrm{E}$, and $\mathrm{IC}_{50}=$ $499.99 \mu \mathrm{g} / \mathrm{mL}$ for the peptide denoted as F). Several peptides were found in the corresponding permeate of raw caprine cheeselike systems, but only 5 inhibited ACE activity. The peptide denoted as $\mathrm{K}$ possessed the lowest activity $\left(\mathrm{IC}_{50}=892 \mu \mathrm{g} / \mathrm{mL}\right)$, whereas the peptide denoted as $\mathrm{H}$ exhibited the highest activity $\left(\mathrm{IC}_{50}=\right.$ $143.70 \mu \mathrm{g} / \mathrm{mL}$ ).

Seven peptides present in the WSE of sterilized caprine cheeselike systems manufactured via crude aqueous extracts of $C$. cardunculus (denoted as L through $\mathrm{R})$ were shown to have ACE-inhibitory activity. The highest activities were accounted for by peptides $\mathrm{L}$ $\left(\mathrm{IC}_{50}=0.58 \mu \mathrm{g} / \mathrm{mL}\right)$ and $\mathrm{M}\left(\mathrm{IC}_{50}=2.45 \mu \mathrm{g} / \mathrm{mL}\right)$, whereas peptide $\mathrm{R}$ exhibited the lowest activity $\left(\mathrm{IC}_{50}=653.98\right.$ $\mu \mathrm{g} / \mathrm{mL})$. Peptide Q $\left(\mathrm{IC}_{50}=116.92 \mu \mathrm{g} / \mathrm{mL}\right)$ was not found in cheeselike systems made with cardosin A.

Chemical sequencing permitted us to determine the peptide bonds cleaved by the coagulating enzymes within $\mathrm{CN}$, from (putative) identification of the peptides (or at least by part of their sequence) released. However, some chromatographic peaks were accounted for by a major peptide accompanied by other minor components (i.e., a mixture of peptides), which made the analysis increase considerably in complexity.

Peptide bonds in $\beta$-CN cleaved by enzymes from $C$. cardunculus included Leu190-Tyr191, Gly94-Val95, Met102-Val103, and Asn73-Ile74, which gave rise to the peptides Tyr-Gln-Glu-Pro, Ile-Leu-Pro, Val-ProLys-Val-Lys, and Tyr-Gln-Glu-Pro-Val-Leu-Gly-Pro-* (see Tables 2, 3). Peptide Tyr-Gln-Glu-Pro-Val-Leu, also found in hydrolyzed bovine milk, was demonstrated to have ACE-inhibitory activity, characterized by an $\mathrm{IC}_{50}$ of $280 \mu M$ (Pihlanto-Leppälä et al., 1998).

In the case of $\alpha_{\mathrm{s} 1}-\mathrm{CN}, \mathrm{N}$-terminal peptides were identified that exhibited ACE-inhibitory activity, namely, Arg-Pro-Lys $\left[\alpha_{\mathrm{s} 1}-\mathrm{CN}\right.$ (1-3)] and Arg-Pro-Lys-His-ProIle-Lys-His-* $\left[\alpha_{\mathrm{s} 1}-\mathrm{CN}(1-*)\right]$. When studying a new type of ripened, low-fat cheese, Ryhänen et al. (2001) also reported that similar peptides from $\alpha_{\mathrm{s} 1}-\mathrm{CN}$ [i.e., $\alpha_{\mathrm{s} 1}-\mathrm{CN}$ (1-9), $\alpha_{\mathrm{s} 1}-\mathrm{CN}$ (1-7), and $\alpha_{\mathrm{s} 1}$-CN (1-6)] possessed ACEinhibitory activity. Moreover, Saito et al. (2000) found $\alpha_{\mathrm{s} 1}$ CN (1-9) from Gouda cheese among the peptides bearing ACE-inhibitory activity $\left(\mathrm{IC}_{50}=13.4 \mu M\right)$, which also showed a weak antihypertensive activity in spontaneously hypertensive rats.

Structure-activity studies involving various peptides that can inhibit $\mathrm{ACE}$ indicate that their binding thereto is strongly influenced by the hydrophobicity and steric size of the AA in the C-terminal position of the peptide (Gobetti et al., 2004; Pripp et al., 2004, 2006). In addition, Cheung et al. (1980) have claimed that ACE prefers substrates or competitive inhibitors that contain such hydrophobic AA residues as Pro, Phe, and Tyr in the C-terminus. Among the peptides experimentally proven to possess ACE-inhibitory activity, only the sequence Tyr-Gln-Glu-Pro has those characteristics; however, Tyr-Gln-Glu-Pro-Val-Leu-Gly-Pro-* may be seen as a precursor of the previous shorter sequence.

Finally, one should emphasize that bioactivity per unit weight of cheese might be more relevant for consumers than the inhibitory strength of peptide fractions isolated from cheese, which will make a difference concerning any health claims of ACE inhibition (Pripp et al., 2006).

The Trolox-equivalent antioxidant capacity (TEAC) assay is based on scavenging of $\mathrm{ABTS}^{\bullet+}$, with concomitant conversion thereof to a colorless product. The degree of decolorization induced by a compound relates to that induced by Trolox, thus yielding a TEAC value, which is often used as a useful tool to detect (unknown) antioxidants (Arts et al., 2004). The TEAC values found for peptides isolated from WSE of raw and sterilized ovine and caprine cheeselike systems are shown in Tables 1 and 2. Although most peptides exhibit low TEAC values compared with those of $\alpha$-tocopherol and vitamin C (0.97 and $0.99 \mathrm{mM}$, respectively, by $6 \mathrm{~min}$; Miller et al., 1993), higher TEAC values were generally found for peptides in WSE from ovine cheeselike systems.

Peptides D, F, and R, from WSE of raw ovine, sterilized ovine, and sterilized caprine cheeselike systems, respectively, presented the highest TEAC values (0.102, 0.124 , and $0.191 \mathrm{mM}$, respectively). A comparison of the TEAC values of such peptides with the TEAC values of others found in the literature (using the $\mathrm{ABTS}^{\bullet+}$ method) indicates that their antioxidant capacity is comparable to that of some sherry wines (Villãno et al., 2004). The aforementioned peptides arise from cleavage of the peptide bond Leu190-Tyr191, either in ovine or caprine $\beta$-CN, and correspond to the sequence Tyr-Gln-Glu-Pro-*. Such a realization is of great importance, because there are no reports to date concerning peptides from cheeses bearing this kind of bioactivity. This provides useful information toward the development of functional food products in the near future, and of additives with proven antioxidant properties.

Difficulties in peptide identification constrain the knowledge encompassing bioactive peptide formation and their release from the precursor proteins. In fact, milk protein hydrolysates are highly complex mixtures that may contain up to hundreds of different peptides. Therefore, identification of such peptides in fermented 
dairy products or in milk protein hydrolysates generated by the action of nonspecific enzymes is a laborintensive and difficult task. This task comprises several purification steps, normally a combination of distinct (and complementary) chromatographic techniques. Each separation step in turn requires solvent removal and assessment of biological activity. In most cases, the final fractions still contain multiple components, which can cause a discrepancy between the activity exhibited by the purified fractions and that by their original counterparts (Gómez-Ruiz et al., 2002; Gobbetti et al., 2004).

\section{CONCLUSIONS}

Raw and sterilized ovine and caprine cheeselike systems, manufactured with proteases from $C$. cardunculus, are a source of peptides with ACE-inhibitory and antioxidant activities. The peptides Tyr-Gln-Glu-Pro, Val-Pro-Lys-Val-Lys, and Tyr-Gln-Glu-Pro-Val-LeuGly-Pro-* from $\beta$-CN, as well as Arg-Pro-Lys and ArgPro-Lys-His-Pro-Ile-Lys-His-* from $\alpha_{\mathrm{s} 1}$-CN exhibited ACE-inhibitory activity. Peptides released upon cleavage of the peptide bond Leu190-Tyr191 (either in ovine or caprine $\beta-\mathrm{CN}$ ), and corresponding to the $\beta$-CN sequence Tyr-Gln-Glu-Pro-*, possessed antioxidant activity. Despite their moderate bioactivity, they intrinsically behave as functional foods, so they may eventually be recommended for inclusion in one's daily diet as a more appealing, health-promoting vector than the direct use of more potent drugs. Moreover, possibilities exist for designing new dietary products as well as for exploiting novel natural drugs, because peptide sequences not previously described in the literature possess such desired bioactivities.

\section{ACKNOWLEDGMENTS}

Financial support for author S. V. Silva was provided by a $\mathrm{PhD}$ fellowship (BD/18479/98) issued by the program PRAXIS XXI [Fundação para a Ciência e Tecnologia (FCT), Portugal]. This research effort received partial financial support by grants associated with projects "Enterococos: Aprofundamento do conhecimento sobre o papel desempenhado por enterococos no fabrico e na maturação natural de queijos tradicionais portugueses" (POCTI/AGR/36165/99) and "MICROCHEESE: MICro-stRucture of pOrtuguese CHEESEs" (POCTI/ 36197/BIO/2000), both issued by the program POCTI (FCT). The availability of laboratory facilities at MTT Agrifood Research Finland is hereby gratefully acknowledged.

\section{REFERENCES}

Addeo, F., L. Chianese, A. Salzano, R. Sacchi, U. Cappuccio, P. Ferranti, and A. Malorni. 1992. Characterization of the $12 \%$ trichloro- acetic acid-insoluble oligopeptides of Parmigiano-Reggiano cheese. J. Dairy Res. 59:401-411.

Antolovich, M., P. D. Prenzler, E. Patsalides, S. McDonald, and K. Robards. 2002. Methods for testing antioxidant activity. Analyst 127:183-198.

Arts, M. J. T. J., G. R. M. M. Haenen, H.-P. Voss, and A. Bast. 2004. Antioxidant capacity of reaction products limits the applicability of the Trolox equivalent antioxidant capacity (TEAC) assay. Food Chem. Toxicol. 42:45-49.

Banks, J. M. 1990. Improving cheese yield by the incorporation of whey powder. Dairy Ind. Int. 55:37-39.

Calvo, M. M., J. Leaver, A. J. R. Law, and J. M. Banks. 1992. Changes in casein levels during the ripening of Cheddar type cheese made from overheated milk. Milchwissenschaft 47:516-518.

Chen, J., H. Lindmark-Månsson, L. Gorton, and B. Åkesson. 2003. Antioxidant capacity of bovine milk as assayed by spectrophotometric and amperometric methods. Int. Dairy J. 13:927-935.

Cheung, H. S., F. I. Wang, M. A. Ondetti, E. F. Sabo, and D. W. Cushman. 1980. Binding of peptide substrates and inhibitors of angiotensin-converting enzyme. Importance of the $\mathrm{COOH}$-terminal dipeptide sequence. J. Biol. Chem. 225:401-407.

Cushman, D. W., and H. S. Cheung. 1971. Spectrophotometric assay and properties of the angiotensin-converting enzyme of rabbit lung. Biochem. Pharmacol. 20:1637-1648.

Dalgleish, D. G. 1987. The enzymatic coagulation of milk. Pages 6396 in Cheese: Chemistry, Physics and Microbiology. P. F. Fox, ed. Elsevier, London.

Frazão, C., I. Bento, J. Costa, C. M. Soares, P. Veríssimo, C. Faro, E. Pires, J. Cooper, and M. A. Carrondo. 1999. Crystal structure of cardosin A, a glycosylated and Arg-Gly-Asp-containing aspartic proteinase from the flowers of Cynara cardunculus L. J. Biol. Chem. 274:27694-27701.

Gobetti, M., L. Stepaniak, M. de Angelis, A. Corsetti, and R. di Cagno. 2004. Latent bioactive peptides in milk proteins: Proteolytic activation and significance in dairy processing. Crit. Rev. Food Sci. Nutr. 42:223-239.

Gómez-Ruiz, J. A., M. Ramos, and I. Recio. 2002. Angiotensin-converting enzyme-inhibitory peptides in Manchego cheeses manufactured with different starter cultures. Int. Dairy J. 12:697-706.

Gómez-Ruiz, J. A., M. Ramos, and I. Recio. 2004. Angiotensin converting enzyme-inhibitory activity of peptides isolated from Manchego cheese. Stability under simulated gastrointestinal digestion. Int. Dairy J. 12:1075-1080.

Hermier, J., and O. Cerf. 2000. Heat treatments. Pages 239-254 in Cheesemaking-From Science to Quality Assurance. A. Eck and J.-C. Gillis, ed. Lavoisier, Paris, France.

Kuchroo, C. N., and P. F. Fox. 1982. Comparison of extraction procedures. Milchwissenschaft 37:331-335.

Maruyama, S., H. Mitachi, J. Awaya, M. Kurono, N. Tonizuka, and H. Suzuki. 1987. Angiotensin I-converting enzyme inhibitory activity of the C-terminal hexapeptide of $\alpha_{\mathrm{s} 1}$-casein. Agric. Biol. Chem. 51:2557-2561.

Meisel, H. 1993. Casokinins as bioactive peptides in the primary structure of casein. Pages 67-75 in Food Proteins: Structure and Functionality. K. D. Schwenke and R. Mothes, ed. VCH-Weinheim, New York, NY.

Meisel, H. 1998. Overview on milk protein-derived peptide. Int. Dairy J. 8:363-373.

Meisel, H., A. Goepfert, and S. Günther. 1997. ACE-inhibitory activities in milk products. Milchwissenschaft 52:307-311.

Miller, N. J., C. A. Rice-Evans, M. J. Davies, V. Gopinathan, and A. Milner. 1993. A novel method for measuring antioxidant capacity and its application to monitoring the antioxidant status in premature neonates. Clin. Sci. 84:407-412.

Pihlanto-Leppälä, A., T. Rokka, and H. Korhonen. 1998. Angiotensin I-converting enzyme inhibitory peptides derived from bovine milk proteins. Int. Dairy J. 8:325-331.

Pripp, A. H., T. Isaksson, L. Stepaniak, and T. Sørhaug. 2004. Quantitative structure-activity relationship modelling of ACE inhibitory peptides derived from milk proteins. Eur. Food Res. Technol. 219:579-583. 
Pripp, A. H., R. Sørensen, L. Stepaniak, and T. Sørhaug. 2006. Relationship between proteolysis and angiotensin-I-converting enzyme inhibition in different cheeses. LWT Food Sci. Technol. 39:677-683.

Re, R., N. Pellegrini, A. Proteggente, A. Pannala, M. Yang, and C. Rice-Evans. 1999. Antioxidant activity applying an improved ABTS radical cation decolorization assay. Free Radic. Biol. Med. 26:1231-1237.

Rival, S. G., C. G. Boerium, and H. J. Wichers. 2001. Caseins and casein hydrolysates. 2 . Antioxidative properties and relevance to lipoxygenase inhibition. J. Agric. Food Chem. 49:295-302.

Ryhänen, E.-L., A. Pihlanto-Leppälä, and E. Pahkala. 2001. A new type of ripened, low-fat cheese with bioactive properties. Int. Dairy J. 11:441-447.

Saito, T., T. Nakamura, H. Kitazawa, Y. Kawai, and T. Itoh. 2000. Isolation and structural analysis of antihypertensive peptides that exist naturally in Gouda cheese. J. Dairy Sci. 83:1434-1440.

Sforza, S., L. Ferroni, G. Galaverna, A. Dossena, and R. Marchelli. 2003. Extraction, semi-quantification, and fast on-line identification of oligopeptides in Grana-Padano cheese by HPLC-MS. J. Agric. Food Chem. 5:2130-2135.

Singh, H., and A. Waungana. 2001. Influence of heat treatment of milk on cheesemaking properties. Int. Dairy J. 11:543-551.

Silva, S. V., T. Allmere, F. X. Malcata, and A. Andrén. 2003. Comparative studies on the gelling properties of cardosins from Cynara cardunculus and chymosin on cow's skim milk. Int. Dairy J. 13:559-564.

Silva, S. V., and F. X. Malcata. 2005a. Milk caseins as a source of bioactive peptides. Int. Dairy J. 15:1-15.
Silva, S. V., and F. X. Malcata. 2005b. Studies pertaining to coagulant and proteolytic activities of plant proteases from Cynara cardunculus. Food Chem. 89:19-26.

Smacchi, E., and M. Gobetti. 1998. Peptides from several Italian cheeses inhibitory to proteolytic enzymes of lactic acid bacteria Pseudomonas fluorescens ATCC 948 and to the angiotensin Iconverting enzyme. Enzyme Microb. Technol. 22:687-694.

Suetsuna, K., H. Ukeda, and H. Ochi. 2000. Isolation and characterization of free radical scavenging activities of peptides derived from casein. J. Nutr. Biochem. 11:128-131.

Tavaria, F. K., and F. X. Malcata. 1998. Microbiological characterization of Serra da Estrela cheese throughout its Appélation d'Origine Protégée Region. J. Food Prot. 61:601-607.

VanderJagt, D. J., S. N. Okolo, A. Constanza, W. Blackwell, and R. H. Glew. 2001. Antioxidant content of the milk of Nigerian women and the sera of their exclusively breast-fed infants. Nutr. Res. 21:121-128.

Veríssimo, P., C. Esteves, C. Faro, and E. Pires. 1995. The vegetable rennet of Cynara cardunculus L. contains two proteinases with chymosin and pepsin-like specificities. Biotechnol. Lett. 17:621-626.

Vermeirssen, V., J.van Camp, and W. Verstraete. 2002. Optimization and validation of an angiotensin-converting enzyme inhibition assay for the screening of bioactive peptides. J. Biochem. Biophys. Meth. 51:75-87.

Villãno, D., M. S. Fernández-Pachón, A. M. Troncoso, and M. C. García-Terrilla. 2004. The antioxidant activity of wines determined by $\mathrm{ABTS}^{\bullet+}$ method: Influence of sample dilution and time. Talanta 64:501-509. 